\title{
Quantification of Antibiotic Residues and Determination of Antimicrobial Resistance Profiles of Microorganisms Isolated from Bovine Milk in Lebanon
}

\author{
Kassaify Zeina $^{1 *}$, Abi Khalil Pamela ${ }^{1}$, Sleiman Fawwak ${ }^{2}$ \\ ${ }^{1}$ Department of Nutrition and Food Sciences, American University of Beirut, Beirut, Lebanon; ${ }^{2}$ Department of Animal and Veteri- \\ nary Sciences, American University of Beirut, Beirut, Lebanon. \\ Email: ${ }^{2}$ zk18@aub.edu.lb,pamabkh@gmail.com, sleimanf@aub.edu.lb
}

Received March 18 ${ }^{\text {th }}, 2013$; revised April 18 ${ }^{\text {th }}, 2013$; accepted April 28 $8^{\text {th }}, 2013$

Copyright (C) 2013 Kassaify Zeina et al. This is an open access article distributed under the Creative Commons Attribution License, which permits unrestricted use, distribution, and reproduction in any medium, provided the original work is properly cited.

\begin{abstract}
The rapid growth of dairy sectors in the Middle East, particularly in Lebanon, led to extensive use of antibiotics to enhance the health and productivity of animals. Prolonged usage may lead to antibiotic residues in foods of animal origin; hence, the emergence of antimicrobial resistant microorganisms. Accurate data on the antibiotic usage in livestock treatment, antibiotic residues and antimicrobial resistances in raw milk in Lebanon are lacking. This study aimed to investigate the types and usages of antibiotics in cattle, their residual levels and the potential microbial resistances in raw milk samples. A questionnaire-based survey identified Gentamicin and Streptomycin as the most frequently used antibiotics. Selected raw milk samples from main dairy farms were then analyzed in duplicate by quantitative ELISA for the antibiotics residual levels. The mean residual levels of Gentamicin and Streptomycin were 90 and $80 \mu \mathrm{g} / \mathrm{L}$, respectively; which are below the allowable maximum residue limit of $200 \mu \mathrm{g} / \mathrm{L}$ as set by the FAO/WHO. Staphylococcus aureus, Listeria monocytogenes, E. coli and total aerobic microorganisms isolated from the milk samples were then tested for resistance against Gentamicin and Streptomycin by the disc agar diffusion method. All the S. aureus, E. coli, and $L$. monocytogenes isolates showed high resistance to Gentamicin. However, $95 \%$ of $S$. aureus, $60 \%$ of $E$. coli and $58 \%$ of L. monocytogenes isolates were resistant to Streptomycin. The obtained results provide evidence that antimicrobial resistant strains of the above pathogens have become remarkably widespread in raw milk. This requires better management for antibiotic usages among livestock farmers to control sources of food contamination and reduce the health risks associated with the development of resistant microbial strains.
\end{abstract}

Keywords: Milk; Antibiotics; Residues; Resistant Pathogens

\section{Introduction}

Antibiotics, the microbiologically produced compounds, are used in humans to treat or prevent certain diseases caused by infectious agents. However, the major antibiotics used for humans either belong to the same general classes or have the same mode of action as those used for animals [1]. A questionnaire-based survey conducted preliminarily by the authors in this study showed that the most commonly used antibiotics in livestock among major Lebanese dairy farmers are Gentamicin and Streptomycin which belong to the Aminoglycoside group of antibiotics. Furthermore, a limited survey conducted by Choueiri [2] on 17 main dairy farms in Lebanon as part

"Corresponding author. of her thesis work also found that Streptomycin and Gentamicin are used in all the surveyed farms. It is also worth mentioning that the exact amounts of antibiotics used by farmers in livestock production in Lebanon are not known since they are not regulated. Streptomycin is mainly used to treat plague and infrequently Brucellosis. It is also combined with penicillin in treating enterococcal and Listeria monocytogenes infections. Gentamicin sulfate is quite effective against several types of bacterial infections mainly those caused by gram-negative bacteria. It is mainly used against Pseudomonas, E. coli, Enterobacteria, Proteus and Serratia [3].

These antibiotics, despite their effectiveness, can leave residues in the treated animal and contaminate its edible parts; the muscle meat and milk [4]. Environmental and 
human health risks are associated with these residues. They range from direct toxicity on consumers exhibiting allergic reactions to indirect problems through the generation of resistant strains of pathogenic bacteria and the residual contamination of manures used in crop productions [5]. To ensure consumer safety, worldwide regulatory authorities have set MRL's (Maximum Residual Limit) for several veterinary drugs $[6,7]$. These MRL's, are expected to regulate the maximum permitted levels of the drug residue for each antibiotic which is considered safely acceptable in food of animal origin [8].

The major worldwide public concern and health hazard associated with antibiotic residues is the development of the antimicrobial resistant bacterial strains of animal origin and its consequent effect on human health [9-13] regarding the efficacy of antimicrobial therapy [14]. As the pathogens have become more resistant to the used doses of antibiotics, incidences of morbidity have increased, therapeutic efficiency has failed, healthcare costs are on the increase, and the antimicrobial doses have increased with scientists occupied searching for alternatives to relieve the burden [15]. According to Prescott and Baggot [16], microbial resistance to aminoglycosides, particularly Streptomycin, Neomycin, and Kanamycin is very common and pathogens present in the milk mainly S. aureus, E. coli O157:H7 and $L$. monocytogenes may easily develop antimicrobial resistance [17-19].

This study aimed to determine the residual levels of the two most commonly used antibiotics, Gentamicin and Streptomycin, in milk samples collected from 24 random dairy farms in Lebanon. The enzyme linked immunosorbant assay (ELISA) being user friendly, sensitive and can be economical when many samples need to be analyzed [20] was the method of choice. Another main objective of this work was to determine and link the resistance prevalence of pathogenic Staphylococcus aureus, Escherichia coli and $L$. monocytogenes isolated from the same milk samples to Streptomycin and Gentamicin residues.

\section{Materials and Methods}

\subsection{Questionnaire-Based Survey on Major Farms}

A Questionnaire-based survey was conducted on twenty six Lebanese dairy cattle farms to identify the most commonly used antibiotics, their dosage, timing of use and the practiced withholding times prior to dispatch. In this survey, farms located only in the Bekaa Valley and Mount Lebanon were visited because the southern region was not accessible. Between July and August, several farms were contacted, only 26 agreed to answer the survey divided as $54.1 \%$ in the Bekaa Valley and $45.8 \%$ in Mount Lebanon. Two of the farms were for meat produc- tion; therefore, the collected data were eliminated. The remaining 24 were divided as nine farms for both milk and meat production and 15 for only milk production. Cattle farms varied in capacity; two were large-scale farms with $>1000$ cows, six were medium-scale with cattle capacity $100-400$ and 16 were small-scale with cattle capacity $<100$. Interviews were conducted with the owners and/or the farmers and the questions were closeended. For instance, farmers were asked about the milking techniques used and their corresponding schedule, the sanitary conditions of the flock, percentage mortality and the feed (composition was important for the medicated feed). In addition, farmers were asked about any treatment administered including the brand name or active compound of the medication, treatment period (date of beginning and end of treatment), withdrawal time and identification number of the veterinary prescription.

\subsection{The Controlled Study}

A 10 days controlled study was performed at the Agricultural Research and Education Center (AREC), Faculty of Agricultural and Food Sciences of the American University of Beirut in the Bekaa of Lebanon. In the study, four Holstein cows aged between 34 and 39 months, that yielded approximately the same daily amount of milk (16 - $18 \mathrm{~kg}$ ) were selected. The cows weighed around 450 $500 \mathrm{~kg}$ and had no signs of disease when inspected. They tested negative for mastitis and were not exposed to any antibiotic treatment for a minimum of eight weeks. Each cow was placed in a labeled separate pen and were all given the same amount of water and feed. The two antibiotics Gentamicin and Streptomycin were selected for this study based on the data acquired from the survey that was performed during this study and described above. Two cows were treated with the antibiotic Gentamicin (Gentaprim, Invesa, Veterinary Industry, Barcelona, Spain) at a concentration of $4 \mathrm{ml} / 100 \mathrm{~kg}$ three times a day for 3 days, and the other two were treated with the antibiotic Streptomycin (Pen and Strep, Norbrook Laboratories Limited, Newry, BT35 6JP) at a concentration of $1 \mathrm{ml} / 25 \mathrm{~kg}$ once a day for five days. Treatments were administered by deep intramuscular injection using sterile disposable syringes $(20 \mathrm{ml}$ syringe, Luer-Lok and BD Microlance $18 \mathrm{G}$ needles) to prevent possible contamination. Milking was performed twice per day; at 2:00 am and 2:00 pm. The milk samples used for analysis consisted of a mixture of both milking times and were collected in $100 \mathrm{ml}$ sterile plastic containers in duplicate. Aseptic measures were taken during sample collection by cleaning and drying the udders before milking and sanitizing the milk buckets before and between every milking session. All samples were analyzed for antibiotic residues and antimicrobial susceptibility. 


\subsection{The Experimental Study}

In order to validate the information provided by the farmers in the Questionnaire-based survey with respect to the withholding periods and the proper dosage of antibiotics used, analyses were conducted on random milk samples collected from the different farms. The 26 farms that were visited for the survey were contacted again and only 22 farms had agreed to provide samples to be analyzed. These farms varied from large-scale (9\%) to mediumscale $(27 \%)$ and small-scale (64\%). Microbiological, antibiotic residues and antimicrobial susceptibility analyses were performed on all the samples in duplicate.

\subsection{Analysis of Antibiotic Residues}

Enzyme linked immunosorbant assay (ELISA) test kits were used to quantitatively analyze both the control and the experimental milk samples for the presence of the two most commonly used antibiotics by the farmers, the aminoglycoside antibiotics Streptomycin and Gentamicin (BIO SCIENTIFIC Austin, TX 78744 USA. ELISA kits 1014 and 1027, respectively). Reagents and samples were prepared according to the ELISA kits instructional manual. Six standard antibiotic concentrations of the Gentamicin (negative control, $0.25 \mathrm{ng} / \mathrm{ml}, 0.75 \mathrm{ng} / \mathrm{ml}, 1.5$ $\mathrm{ng} / \mathrm{ml}, 3.0 \mathrm{ng} / \mathrm{ml}$ and $15 \mathrm{ng} / \mathrm{ml}$ ) and 42 prepared milk test samples (20 samples from the control study and 22 experimental samples collected from various farms) were pipetted in duplicate into different wells. ELISA procedure was followed according to the provided manufacturers' instructional material. Absorbance was read on a micro titer plate reader with $450 \mathrm{~nm}$ wavelength. The same procedure was followed for Streptomycin analyses but the standards provided were; negative control, 0.5 $\mathrm{ng} / \mathrm{ml}, 1 \mathrm{ng} / \mathrm{ml}, 2.5 \mathrm{ng} / \mathrm{ml}, 5 \mathrm{ng} / \mathrm{ml}$ and $10 \mathrm{ng} / \mathrm{ml}$.

\subsection{Microbiological Analysis of Milk Samples}

A total of 30 raw milk samples collected from the various farms and from the control study were microbiologically analyzed following the procedure of the bacteriological analytical manual [21]. The samples were tested for the presence of Staphylococcus aureus, E. coli, Listeria monocytogenes, Listeria innocua, total aerobic count and total coliforms. In the procedure, for the enumeration of E. coli and the total aerobic microorganisms, a $10 \mathrm{ml}$ portion of each milk sample was aseptically diluted with $90 \mathrm{ml}$ of sterilized peptone-water $(\mathrm{PW})^{1}$. Serial dilutions from $10^{-1}$ to $10^{-3}$ were prepared and an aliquot of $0.1 \mathrm{ml}$ of the homogenate was spread on Plate Count Agar ${ }^{1}$ plates for the total aerobic count while Rapid E. coli (REC 2/agar) ${ }^{1}$ agar was used by the pour plate technique

${ }^{1}$ BIO-RAD; boulevard Raymond-Poincare 92430, Marnes-La-CoquetteFrance. for the enumeration of $E$. coli. Plates were then incubated for 48 hours at $37^{\circ} \mathrm{C}$. All colonies on PCA and REC were enumerated; purple-pink colonies were identified as $E$. coli, whereas blue colonies as coliforms. For S. aureus, a $25 \mathrm{ml}$ portion of each sample was treated in an equivalent manner, but diluted with $225 \mathrm{ml} \mathrm{PW}$ and plated on Rapid Staphylococcus (R. Staph) ${ }^{1}$ agar plates. Selected black colonies with a white ring were enumerated and tested for coagulase and catalase activity using the Pastorex (Staph plus/Latex) ${ }^{1}$ test as a biochemical confirmation test [21]. Finally, the presence of L. monocytogenes was assessed by taking an additional $25 \mathrm{ml}$ portion of each sample and diluted with sterile Listeria Enrichment Broth (Fraser 1 broth) ${ }^{1}$ supplemented with Listeria Enrichment Broth Supplement (Fraser 1/2 broth supplement ${ }^{1}$ and spread on plates of Palcam agar (Palcam) ${ }^{1}$ supplemented with Palcam supplement ${ }^{1}$. Black colonies were identified as presumptive L. monocytogenes, whereas white colonies were presumptive L. innocua. Then, Frazer One supplement (Frazer 1 broth supplement), (0.1 $\mathrm{ml} / 1 \mathrm{ml}$ ) was added to the homogenate to further enrich the remaining Listeria species for complete detection and were incubated for another 24 hours at $30^{\circ} \mathrm{C}$. $0.1 \mathrm{ml}$ of serial dilutions from $10^{-1}$ to $10^{-3}$ were then plated on Palcam agar plates in duplicate. The suspected colonies of L. monocytogenes, L. innocua, S. aureus, E. coli and coliforms were then isolated and frozen stocks of each isolate were prepared in sterile microtubes with $1 \mathrm{ml}$ of $30 \%$ glycerol and stored at $-20^{\circ} \mathrm{C}$ to be used in the subsequent susceptible tests.

\subsection{Antimicrobial Susceptibility Tests}

Bacterial isolates from the milk samples were tested for antimicrobial susceptibility using the disc agar diffusion method according to the procedures recommended by the Clinical and Laboratory Standards Institute (CLSI) [22]. Gentamicin and Streptomycin, the most commonly used antibiotics, were chosen to assess the resistance of the isolated pathogens. Bacterial isolates from the above microbiological analyses were grown on PCA plates. Streptomycin and Gentamicin (10 $\mu \mathrm{g}$, BIORAD) antibiotic discs and empty discs as control were tested on duplicate plates. The plates were incubated for 24 hours at $37^{\circ} \mathrm{C}$ and the zones of inhibition were measured with a metric ruler and interpreted as resistant or sensitive according to the CLSI guidelines. Predisposed strains did not grow in the area around the disc; whereas, resistant strains endured the antibiotic.

\subsection{Statistical Analyses}

Data subjected to statistical analysis were analyzed using the software SPSS 15.0 for Windows Evaluation Version. Gentamicin and Streptomycin residue levels were com- 
pared by means of 1-way ANOVA at $P<0.05$ among the milk samples from the selected farms to determine if antibiotic usage among farmers were similar. Concerning the antimicrobial resistance patterns in milk, statistical analyses (Chi-square analysis at $P<0.05$ ) were conducted to compare resistance patterns to Gentamicin with resistance patterns to Streptomycin. To verify if a relation between Streptomycin or Gentamicin residue levels and microorganism levels in the milk samples exists, regression analysis was conducted at $P<0.05$.

\section{Results}

The main recurrent antibiotics used among the interviewed farmers were Gentamicin, Canamycin, Penicillin, Oxytetracyclin, Tetracycline and Streptomycin with Gentamicin and Streptomycin being the most frequently used ( $88 \%$ and $92 \%$ respectively). All farmers reported treating their cattle only during illness in doses specified either by the veterinarian or according to the manufacturer's instructions on the label. They also claimed to give the antibiotic treatment for as long as specified and withhold as directed.

\subsection{Analysis of Antibiotic Residues}

\subsubsection{Controlled Study}

This aimed to determine from a controlled study of a known antibiotic dosage, the residual levels of antibiotics during withholding days to compare with the experimental samples and validate farmers' claims. Both cows that were treated with Gentamicin had similar antibiotic residue levels in their milk samples throughout the 10-day interval of the study. On average, an initial residue level of $107 \mathrm{ng} / \mathrm{ml}$ of Gentamicin was noticed in the milk samples on day one followed by a peak residue level of 132 $\mathrm{ng} / \mathrm{ml}$ on day 4 and a decrease to $57 \mathrm{ng} / \mathrm{ml}$ on the 10 th day (Figure 1). However, on the 7th day, the final day of withholding period according to the directions, Gentamicin residue levels reached a mean concentration of $71.6 \mathrm{ng} / \mathrm{ml}$ (Figure 1).

Similarly, the initial Streptomycin residue level was $108 \mathrm{ng} / \mathrm{ml}$ on day one followed by a peak of $120 \mathrm{ng} / \mathrm{ml}$ on day 2 and a decrease to $74 \mathrm{ng} / \mathrm{ml}$ of Streptomycin residue levels on the 10th day. At the 6th day, the final day of withholding period as directed, Streptomycin residue levels reached a mean of $107.91 \mathrm{ng} / \mathrm{ml}$ (Figure 2).

\subsubsection{Experimental Samples}

The random experimental milk samples were also analyzed for Gentamicin and Streptomycin.

The levels of Gentamicin and Streptomycin residues in all the tested samples were less than the recommended maximum residue limit as set by the $\mathrm{FAO} / \mathrm{WHO}$; MRL = $200 \mu \mathrm{g} / \mathrm{L}$ (Table 1). This result in milk indicates that the

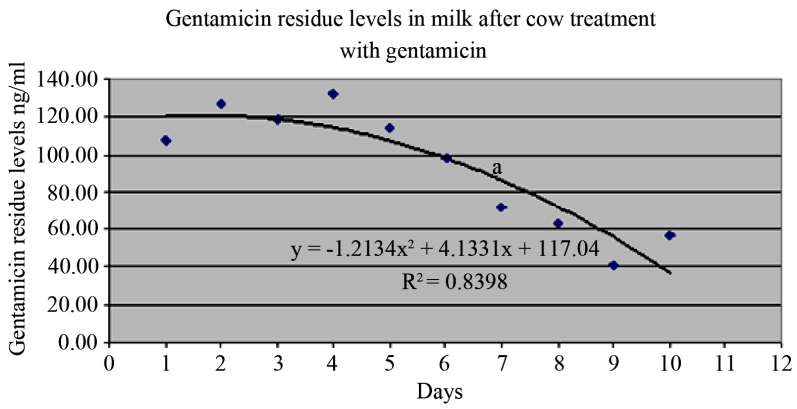

$\mathrm{a}=$ Gentamicin residue level at day 7 , the international specified day for withholding after treatment of cattle with Gentamicin; Sample detection limit $=2.5 \mathrm{ng} / \mathrm{ml}$; Number of samples $=20$ (10 from each cow $)$.

Figure 1. Mean Gentamicin residue levels in milk samples collected for 10 days after treating 2 control cows with Gentamicin.

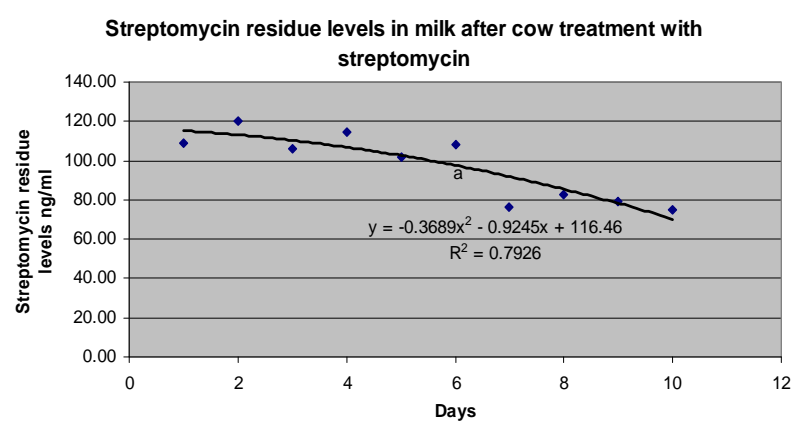

$\mathrm{a}=$ Streptomycin residue level at day 7 , the international specified day for withholding after treatment of cattle with Streptomycin; Sample detection limit $=2.5 \mathrm{ng} / \mathrm{ml} ;$ Number of samples $=20 ; 10$ from each cow.

Figure 2. Mean Streptomycin residue levels in milk samples collected for 10 days after treatment of 2 cows with Streptomycin.

application doses by Lebanese farmers may not be exceeding the recommendations. In addition, the milk samples collected from the selected farms had their Gentamicin and Streptomycin residue levels equivalent to those obtained from the milk samples in the controlled study post the required withholding period ( 71 and 107 $\mathrm{ng} / \mathrm{ml}$, respectively).

\subsection{Microbiological Analysis of Milk Samples}

\subsubsection{Controlled study}

All tested samples were contaminated with $S$. aureus $\left(10^{3}\right.$ to $\left.10^{4} \mathrm{CFU} / \mathrm{g}\right)$ and L. monocytogenes $\left(10^{6}\right.$ to $\left.10^{7} \mathrm{CFU} / \mathrm{g}\right)$; while $62.5 \%$ of the milk samples had their total aerobic counts ranging between $10^{3}$ and $10^{4} \mathrm{CFU} / \mathrm{g}$. None of the samples had E. coli; whereas, $12.5 \%$ of samples had total coliform levels between $10^{4}$ and $10^{5} \mathrm{CFU} / \mathrm{g}$. Finally, $L$. innocua was detected in $62.5 \%$ of the tested samples.

\subsubsection{Experimental Samples}

Microbiological results of the raw milk samples collected from the various selected farms showed a mean value of 
Table 1. Gentamicin and Streptomycin residue levels in raw milk samples collected from the selected farms.

\begin{tabular}{ccccc}
\hline $\begin{array}{c}\text { Selected } \\
\text { farms }\end{array}$ & $\begin{array}{c}\text { Streptomycin } \\
\text { (ng/ml) }\end{array}$ & $\begin{array}{c}\text { Standard } \\
\text { error }\end{array}$ & $\begin{array}{c}\text { Gentamicin } \\
\text { (ng/ml) }\end{array}$ & $\begin{array}{c}\text { Standard } \\
\text { error }\end{array}$ \\
\hline F 1 & 48.92 & 0.18 & 63.91 & 0.06 \\
F 2 & 31.27 & 0.09 & 48.66 & 0.06 \\
F 3 & 63.05 & 0.06 & 49.71 & 0.33 \\
F 4 & 40.80 & 0.08 & 46.32 & 0.02 \\
F 5 & 53.76 & 0.07 & 50.13 & 0.03 \\
F 6 & 59.53 & 0.04 & 41.81 & 0.17 \\
F 7 & 55.61 & 0.11 & 53.52 & 0.14 \\
F 8 & 52.48 & 0.06 & 72.77 & 0.01 \\
F 9 & 48.08 & 0.05 & 69.86 & 0.04 \\
F 10 & 29.43 & 0.01 & 45.27 & 0.06 \\
F 11 & 48.08 & 0.06 & 75.89 & 0.00 \\
F 12 & 60.89 & 0.04 & 58.42 & 0.02 \\
F 13 & 9.22 & 0.16 & 29.44 & 0.02 \\
F 14 & 67.61 & 0.06 & 61.26 & 0.01 \\
F 15 & 65.41 & 0.08 & 60.72 & 0.12 \\
F 16 & 13.43 & 0.01 & 21.39 & 0.02 \\
F 17 & 45.16 & 0.38 & 52.97 & 0.07 \\
F 18 & 65.21 & 0.10 & 71.22 & 0.00 \\
F 19 & 36.52 & 0.18 & 85.07 & 0.08 \\
F 20 & 5.10 & 0.02 & 39.20 & 0.06 \\
F 21 & 51.64 & 0.18 & 67.99 & 0.05 \\
F 22 & 65.25 & 0.14 & 72.07 & 0.02 \\
\hline
\end{tabular}

Sample detection limit $=2.5 \mathrm{ng} / \mathrm{ml} ; \mathrm{N}=22$ farms; $\mathrm{F}=$ farm.

total aerobic counts $>10^{6} \mathrm{CFU} / \mathrm{g}$ in $58 \%$ of the tested samples. Most of the analyzed samples $(95 \%)$ contained Staphylococcus aureus in the range of $10^{5}-10^{6} \mathrm{CFU} / \mathrm{ml}$. As for $L$. monocytogenes, it was detected in $19(86 \%)$ of the 22 milk samples while $L$. innocua was detected only in $46 \%$ of the samples. Finally, $55 \%$ and $28 \%$ of the raw milk samples had a mean value of $10^{5} \mathrm{CFU} / \mathrm{g}$ of coliforms and $10^{4} \mathrm{CFU} / \mathrm{g}$ of $E$. coli respectively. The distributions of bacteriological counts obtained are summarized in Table 2.

\subsection{Antimicrobial Susceptibility Tests}

\subsubsection{Controlled Study}

The possibility of the development of resistant microorganisms to the two selected antibiotics was investigated in the control milk samples. A total of 15 (78\%) microbial isolates showed some resistance to Gentamicin and six out of the 19 isolates (32\%) showed resistance patterns to Streptomycin. Only six out of the 19 microbial isolates (32\%) showed antimicrobial multi-resistant patterns to both Streptomycin and Gentamicin.

\subsubsection{Experimental Samples}

Antimicrobial resistance of microorganisms isolated from the experimental milk samples was also tested and the resistance patterns of the isolates are summarized in Table 3. A significantly $(P<0.05)$ high number of coliforms (9 isolates) and Listeria monocytogene (16 isolates) that were isolated from different milk samples showed resistance to Gentamicin; whereas, only 5 isolates of coliform and 10 isolates of $L$. monocytogenes were resistant to Streptomycin. The remaining isolates of L. innocua, S. aureus and E. coli isolated were resistant to both Gentamicin and Streptomycin (Table 3).

\section{Discussion}

The rapid growth of the dairy sector in the Middle East and the lack of accurate data on the usage of antibiotics particularly in Lebanon necessitated the investigation of the potential presence of antibiotic residues in milk and the adverse health risks associated with the development of antimicrobial resistant pathogens. The questionnairebased survey identified the most commonly used antibiotics among the Lebanese dairy farmers and generated data that were used in the consequent analytical parts of this study. This approach helped to envision the antimicrobial usage on a detailed basis by interviewing the farmers. The information collected from the various owners and/or supervisors of the farms about the application dosage, timing of intervention, adherence to withholding times and other international standards were validated by the experimental part of this study. The data that were analyzed for the most commonly used two antibiotics Gentamicin and Streptomycin showed insignificant discrepancy between the provided information and the experimental results. This finding is important towards alleviating concerns about the improper usage of antibiotics in cattle and their residues in dairy products.

\subsection{Analysis of Antibiotic Residues}

Various studies have indicated that the exposure of animals to antimicrobial agents result in microbial resistance to antibiotics which is possibly transferred to human pathogens [23-26]. In addition, human exposure to significant levels of antibiotic residues from animal products may aggravate immunological responses in susceptible individuals and negatively affect the intestinal microbiota $[26,27]$. Therefore; in this preliminarily study the possible presence and level of antibiotic residues in milk samples from selected farms were investigated. The farmers' compliance to withholding periods and proper usage of such drugs were also established by comparing antibiotic residue levels in the experimental samples with those obtained from the controlled study. Although the results 
Table 2. Percentage of samples tested positive for $L$. monocytogenes, L. innocua, S. aureus, E. coli, coliforms and total aerobic counts found in raw milk samples collected from 22 randomly selected cattle farms in Lebanon.

\begin{tabular}{|c|c|c|c|c|c|c|c|}
\hline Type of bacteria & $0 \mathrm{ND}^{*}(\%)$ & $\begin{array}{c}<10^{3} \text { CFU/g } \\
(\%)\end{array}$ & $\begin{array}{c}10^{3} \text { to } 10^{4} \mathrm{CFU} / \mathrm{g} \\
(\%)\end{array}$ & $\begin{array}{c}10^{4} \text { to } 10^{5} \mathrm{CFU} / \mathrm{g} \\
(\%)\end{array}$ & $\begin{array}{c}10^{5} \text { to } 10^{6} \mathrm{CFU} / \mathrm{g} \\
(\%)\end{array}$ & $\begin{array}{c}10^{6} \text { to } 10^{7} \mathrm{CFU} / \mathrm{g} \\
(\%)\end{array}$ & Total $(\%)^{* * * *}$ \\
\hline $\mathrm{TAC}^{* *}$ & 0 & $9^{* * *}$ & 14 & 14 & 5 & 58 & $22(100)$ \\
\hline S. aureus & & 14 & 27 & 9 & 41 & 4 & $21(95)$ \\
\hline Coliform & 45 & 18 & 18 & 19 & 0 & 0 & $12(55)$ \\
\hline E. coli & 72 & 23 & 5 & 0 & 0 & 0 & $6(28)$ \\
\hline L. mono & 14 & 23 & 9 & 27 & 18 & 9 & $19(86)$ \\
\hline L. innocua & 54 & 5 & 14 & 27 & 0 & 0 & $10(46)$ \\
\hline
\end{tabular}

*ND not detected in $25 \mathrm{~g}$ of sample tested; ${ }^{* *}$ Total aerobic count; ${ }^{* * *}$ Percentage of samples having a mean count in the specified range; ${ }^{* * * *}$ Total number of samples tested positive - number of samples tested negative for the microorganism; N: number of milk samples $=22$.

Table 3. Resistance, multiresistance and intermediate resistance patterns of microorganisms in the milk samples to Gentamicin and Streptomycin.

\begin{tabular}{cccc}
\hline \multirow{2}{*}{ Microorganism } & \multirow{2}{*}{$\begin{array}{c}\text { Number of } \\
\text { isolates }\end{array}$} & \multicolumn{2}{c}{$\mathbf{N}(\%)$ isolates resistant to } \\
\cline { 3 - 4 } & 21 & $21(100)^{\mathrm{a}}$ & $20(95)^{\mathrm{a}}$ \\
S. aureus & 10 & $10(100)^{\mathrm{a}}$ & $6(60)^{\mathrm{a}}$ \\
E. coli & 9 & $9(100)^{\mathrm{a}}$ & $5(55)^{\mathrm{b}}$ \\
Coliforms & 17 & $16(94)^{\mathrm{a}}$ & $10(58)^{\mathrm{b}}$ \\
L. monocytogenes & 7 & $7(100)^{\mathrm{a}}$ & $6(85)^{\mathrm{a}}$ \\
\hline L. inocua & 7 &
\end{tabular}

Percentages in same row with different superscripts are significantly different at $P<0.05 ; \mathrm{GM}=$ Gentamicin; $\mathrm{SM}=$ Streptomycin. ${ }^{*}$ Number of isolates isolated from the milk samples for each microorganism. ${ }^{* *}$ Number and percentage of isolates of each microorganism resistant to Gentamicin and Streptomycin.

obtained in this study show a widespread usage of Streptomycin and Gentamicin in Lebanon, a general compliance with international regulations for their uses and proper withdrawal times were evident. However, since all the samples collected from the visited farms contained a certain level of antibiotic residues, this may imply a repeated and prolonged treatment of dairy cattle with these antibiotics. Hence, despite the fact that the usage in general is in compliance with regulations with respect to dosages and withholding periods, the excessive and extended applications among farmers may result in the development of antimicrobial resistant microorganisms in raw milk. This hypothesis was further investigated in this study for the main pathogenic microorganisms isolated from the various milk samples. In other studies, for instance, S. aureus has been reported to frequently show multiple antimicrobial resistance patterns [28-31].

\subsection{Microbiological Analysis of Milk Samples}

The unnecessary use of therapeutic doses of antibiotics or as growth promoters in producing animals may be a main cause for the selection of multiple resistant strains of bacterial pathogens which can result in serious human and animal infections $[32,33]$. The microbiological analyses of both the experimental and control raw milk samples in this study allowed for the selection of the commonly present microorganisms in milk to be tested for antibiotic resistance against Gentamicin and Streptomycin. Interestingly, when comparing the microbiological levels in the samples to the microbiological criteria as set by the Commission Regulation [34], total aerobic counts, $L$. monocytogenes and S. aureus exceeded the limit allowed by the legislation for raw milk samples. As for $E$. coli and coliforms, although present in the milk samples, their levels were acceptable. These findings although not the main scope of this study, indicate a possible health risk because $S$. aureus may produce a heat stable toxin in raw milk $[35,36]$. Furthermore, S. aureus has been known to be the most prevalent pathogen to cause intramammary infections in dairy ruminants leading to major economic losses [37,38]. However, the S. aureus isolated from the above samples were resistant to both Gentamicin and Streptomycin (Table 3) and this result is quite alarming because if the drugs were or are to be used to treat and control the condition, regular doses may no longer be effective; thus, promoting a high health and residual levels risk on the animals and humans. Another serious pathogen, L. monocytogenes, was also isolated from all collected milk samples. L. monocytogenes has been linked with numerous outbreaks associated with milk and milk products [39-41]. This pathogen may have contaminated the milk samples through inadequate sanitation during milking, storage and transport or from infected cows on the farms [42]. Thus, proper animal monitoring and handling techniques for milk should be applied on Lebanese farms. Furthermore, poor environmental sanitation noticed during the farm visits may be the cause for the elevated levels of total coliforms and $E$. coli in the analyzed milk samples. Studies have shown that $E$. coli, a normal habitat of human and animal intestines, when constantly gets exposed to antibiotics; it de- 
velops resistance in order to survive. When these resistant isolates are excreted to the environment by feces, they tend to spread resistance genes by vertical gene transfer to pathogens [43-45]. Thus, this will result in resistance to antimicrobial drugs used in treating infectious diseases leading to serious health implications in both humans and animals [46-48].

The above risks are reflected in the results that showed all isolated microorganisms from the experimental and the controlled study samples resistant to Gentamicin (Table 3). With respect to Streptomycin, the findings were as alarming because all microorganisms, except for $E$. coli and coliforms isolated from the controlled milk samples, showed various resistance patterns. This may indicate that a high percentage of the milk supply in the Lebanese market may contain resistant strains of major pathogens against the two drugs, Gentamicin and Streptomycin, commonly used in therapeutic treatments; thus, incurring a major public health concern. The excessive use of Gentamicin and Streptomycin among the farms may be a main cause for the emerging of antimicrobialresistant bacterial pathogens [49]. Furthermore, according to Prescott and Baggot [16] resistance of animal pathogens to aminoglycosides, particularly Streptomycin is very common.

\subsection{Conclusion}

The findings of this study preliminarily validated the claims of dairy Lebanese farmers about the proper usages of antibiotics with respect to doses and withholding periods. However, the results highlighted a potential public health problem reflected in the development of multiresistant pathogenic bacteria to both Gentamicin and Streptomycin. A nationwide study is necessary in the near future with more in depth analyses of the isolated resistant pathogens perhaps at the genotypic levels.

\section{Acknowledgements}

The researchers would like to thank the University Research Board at the American University of Beirut for funding this study, the Agricultural Research and Education Center (AREC), Faculty of Agricultural and Food Sciences of the American University of Beirut for making the controlled study possible, farmers and our laboratory technician for helping in the analysis.

\section{REFERENCES}

[1] S. Joshi, "HPLC Separation of Antibiotics Present in Formulated and Unformulated Samples," Journal of Pharmaceutical and Biomedical Analysis, Vol. 28, No. 5, 2002, pp. 795-809. doi:10.1016/S0731-7085(01)00706-3

[2] M. Choueiri, "Emerging Contaminants in Lebanon: Anti- biotic Residues in Cow Manure and Soil," MS Thesis, American University of Beirut, Beirut, 2008.

[3] W. C. John and E. H. Fred, "Antibiotics: III; Mechanism of Action of Antimicrobial and Antitumor Agents," Springer-Verlag, New York, 1975.

[4] A. A. Bergwerff and J. Schloesser, "Antibiotics and Drugs Residue Determination," Encyclopaedia of Food Science, Food Technology and Nutrition, 2003, p. 254.

[5] M. Dubois, D. Fluchard, E. Sior and P. H. Delahaut, "Identification and Quantification of Five Macrolide Antibiotics in Several Tissues, Eggs and Milk by Liquid Chromatography-Electrospray Tandem Mass Spectrometry," Journal of Chromatography B: Biomedical Sciences and Applications, Vol. 753, No. 2, 2001, pp. 189-202. doi:10.1016/S0378-4347(00)00542-9

[6] The Council of the European Communities, "Council Regulation (EEC) No.2377/90," Official Journal of the European Communities, No. L 224/P, 1990, pp. 1-8.

[7] Food and Drug Administration, "Tolerances for Residues of New Animal Drugs in Food," 2008.

http://www.accessdata.fda.gov/scripts/cdrh/cfdocs/cfefr/C FRSearch.cfm?fr=530.41

[8] K. N. Woodward, "Antibiotics and Drugs Uses in Food Production," Encyclopedia of Food Science, Food Technology and Nutrition, 1993, p. 249.

[9] F. M. Aarestrup, "Antimicrobial Resistance in Bacteria of Animal Origin,” ASM Press, Washington DC, 2006.

[10] L. Guardabassi, S. Schwarz and D. H. Lloyd, "Pet Animals as Reservoirs of Antimicrobial-Resistant Bacteria," Journal of Antimicrobial Chemotherapy, Vol. 54, No. 2, 2004, pp. 321-332. doi:10.1093/jac/dkh332

[11] I. Phillips, M. Casewell, T. Cox, B. De Groot, C. Friis, R. Jones, C. Nightingale, R. Preston and J. Waddell, "Does the Use of Antibiotics in Food Animals Pose a Risk to Human Health? A Critical Review of Published Data," Journal of Antimicrobial Chemotherapy, Vol. 53, No. 1, 2004, pp. 28-52. doi:10.1093/jac/dkg483

[12] D. L. Smith, J. Dushoff and J. G. Morris, "Agricultural Antibiotics and Human Health," PLoS Medicine, Vol. 2, No. 8, 2005, p. 232. doi:10.1371/journal.pmed.0020232

[13] E. J. Threlfall, “Antimicrobial Drug Resistance in Salmonella: Problems and Perspectives in Food- and WaterBorne Infections," FEMS Microbiology Reviews, Vol. 26, No. 2, 2002, pp. 141-148.

[14] A. Casadevall, "Crisis in Infectious Diseases: Time for a New Paradigm?" Clinical Infectious Diseases, Vol. 23, No. 4, 1996, pp. 790-794. doi:10.1093/clinids/23.4.790

[15] T. C. Eickhoff, "Antibiotics and Nosocomial Infections," In: J. V. Bennett and P. S. Brachman, Eds., Hospital Infections, 3rd Edition, Little, Brown and Company, Boston, 1992, pp. 245-264.

[16] J. F. Prescott and J. D. Baggot, "Antimicrobial Therapy in Veterinary Medicine," Iowa State University Press, Ames, 1993.

[17] F. Peles, M. Wagner, L. Varga, I. Hein, P. Rieck, K. Gutser, P. Keresztúri, G. Kardos, I. Turcsányi, B. Béri and A. Szabó, "Characterization of Staphylococcus aureus Strains 
Isolated from Bovine Milk in Hungary," International Journal of Food Microbiology, Vol. 118, No. 2, 2007, pp. 186-193. doi:10.1016/j.ijfoodmicro.2007.07.010

[18] P. M. Griffin and A. V. Tauxe, "The Epidemiology of Infections Caused by Escherichia coli O157:H7, Other Enterohemorrhagic E. coli and the Associated Hemolytic Uremic Syndrome," Epidemiologic Reviews, Vol. 13, 1991, pp. 60-98.

[19] H. P. R. Seeliger and D. Jones, “Genus Listeria,” In: J. G. Holt, Ed., Bergey's Manual of Systematic Bacteriology, Vol. 2, 8th Edition, Williams and Wilkins, Baltimore, 1986, pp. 1235-1245.

[20] B.-C. Ye, S. Y. Li, P. Zuo and X.-H. Li, "Simultaneous Detection of Sulfamethazine, Streptomycin, and Tylosin in Milk by Microplate-Array Based SMM-FIA," Food Chemistry, Vol. 106, No. 2, 2007, pp. 797-803. doi:10.1016/j.foodchem.2007.06.006

[21] H. A. Wallace, G. A. June, P. S. Sherrod, T. S. Hammack and R. M. Amaguana, "Salmonella," In FDA Bacteriological Analytical Manual, 8th Edition, Washington DC, 1995.

[22] Clinical and Laboratory Standards Institute, "Performance Standards for Antimicrobial Susceptibility Tests," National Committee for Clinical Laboratory Standards, Wayne, 2009.

[23] C. Chauvin, S. Le Bouquin-Leneveu, A. Hardy, D. Haguet, J. P. Orand and P. Sanders, "An Original System for the Continuous Monitoring of Antimicrobial Use in Poultry Production in France," Journal of Veterinary Pharmacology and Therapeutics, Vol. 28, No. 6, 2005, pp. 515-523. doi:10.1111/j.1365-2885.2005.00697.x

[24] A. L. Aronson, "Potential Impact of the Use of Antimicrobial Drugs in Farm Animals on Public Health," Presented at the Meeting on Pharmacology in the Animal Health Sector, Colorado State University, 1975.

[25] H. D. Mercer, "Antimicrobial Drugs in Food Producing Animals," Veterinary Clinics of North America, Vol. 5, 1977, pp. 3-5.

[26] S. D. Holmberg, M. T. Osterholm, K. A. Senger and M. L. Cohen, "Drug-Resistant Salmonella from Animals Fed Antimicrobials," New England Journal of Medicine, Vol. 311, No. 10, 1984, pp. 617-622. doi:10.1056/NEJM198409063111001

[27] P. H. Archimbault, "Persistence in Milk of Active Antimicrobial Intramammary Substances. Veterinary Pharmacology and Toxicology," MTP Press Ltd., Lancaster, 2005.

[28] M. C. Enright, "The Evolution of Resistant PathogenThe Case of MRSA," Current Opinion in Pharmacology, Vol. 3, No. 5, 2003, pp. 474-479. doi:10.1016/S1471-4892(03)00109-7

[29] N. H. Kwon, K. T. Park, J. S. Moon, W. K. Jung, S. H. Kim and J. M. Kim, "Staphylococcal Cassette Chromosome $\mathrm{Mec}(\mathrm{SCCmec})$ Characterization and Molecular Analysis for Methicillin-Resistant Staphylococcus aureus and Novel SCCmec Subtype IVg Isolated from Bovine Milk in Korea," Journal of Antimicrobial Chemotherapy, Vol. 56, No. 4, 2005, pp. 624-632. doi:10.1093/jac/dki306
[30] R. O’Mahony, Y. Abbott, F. C. Leonard, B. K. Markey, P. J. Quinn and P. J. Pollock, "Methicillin-Resistant Staphylococcus aureus (MRSA) Isolated from Animals and Veterinary Personnel in Ireland," Veterinary Microbiology, Vol. 109, No. 3-4, 2005, pp. 285-296. doi:10.1016/j.vetmic.2005.06.003

[31] J. L. Wylie and D. L. Nowicki, "Molecular Epidemiology of Community- and Health Care-Associated MethicillinResistant Staphylococcus aureus in Manitoba, Canada," Journal of Clinical Microbiology, Vol. 43, No. 6, 2005, pp. 2830-2836. doi:10.1128/JCM.43.6.2830-2836.2005

[32] WHO, "Surveillance for the Prevention and Control of Health Hazards Due to Antibiotic Resistant Enterobacteria," Technical Report Series 624, 1978.

[33] D. A. Barber, G. Y. Miller and P. E. McNamara, "Models of Antimicrobial Resistance and Food-Borne Illness: Examining Assumptions and Practical Application," Journal of Food Protection, Vol. 66, No. 4, 2003, pp. 700-709.

[34] The Council of the European Communities, "Council Regulation (EEC) No. 2073/2005," Official Journal of the European Communities, No. L 338, 2005, pp. 1-26.

[35] G. Normanno, G. La Salandra, A. Dambrosio, N. C. Quaglia, M. Corrente, A. Parisi, G. Santagada, A. Firinu, E. Crisetti and G. V. Celano, "Occurrence, Characterization and Antimicrobial Resistance of Enterotoxigenic Staphylococcus aureus Isolated from Meat and Dairy Products," International Journal of Food Microbiology, Vol. 115, No. 3, 2007, pp. 290-296.

doi:10.1016/j.ijfoodmicro.2006.10.049

[36] M. L. Marco and M. H. J. Wells-Bennik, "Impact of Bacterial Genomics on Determining Quality and Safety in the Dairy Production Chain," International Dairy Journal, Vol. 18, No. 5, 2008, pp. 486-495.

[37] O. Akineden, C. Annemüller, A. Hassan, C. Lämmler, W. Wolter and M. Schöck, "Toxin Genes and Other Characteristics of Staphylococcus aureus Isolates from Milk of Cows with Mastitis," Clinical and Diagnostic Laboratory Immunology, Vol. 8, No. 5, 2001, pp. 959-964.

[38] A. Pengov, C. V. Flajs, T. Zadnik, J. Marinsek and M. Pogacnik, "Distribution of Chloramphenicol Residues in Lactating Cows Following an External Application," Analytica Chimica Acta, Vol. 529, No. 1-2, 2005, pp. 347-351. doi:10.1016/i.aca.2004.07.035

[39] D. W. Flemming, S. L. Cochi, K. L. Mackonald, J. Brondum, P. S. Hayes and B. D. Plikaytis, "Pasteurised Milk as a Vehicle of Infection in an Outbreak of Listeriosis," New England Journal of Medicine, Vol. 312, 1985, pp. 404-407. doi:10.1056/NEJM198502143120704

[40] M. J. Linnan, L. Mascola, X. D. Lou, V. Goulet, S. May, C. Salminen, D. W. Hird, M. L. Yonekura, P. Hayes, R. Weaver, A. Audurier, B. D. Plikaytis, S. L. Fannin, A. Kleks and C. V. Broome, "Epidemic Listeriosis Associated with Mexican Style Cheese," New England Journal of Medicine, Vol. 319, 1988, pp. 823-828. doi:10.1056/NEJM198809293191303

[41] O. Lyytikainen, T. Autio, R. Maijala, P. Ruutu, T. Honkanen-Buzalski and M. Miettinen, "An Outbreak of Listeria Monocytogenes Serotype 3a Infections from Butter 
in Finland," Journal of Infectious Diseases, Vol. 181, No. 5, 2000, pp. 1838-1841. doi:10.1086/315453

[42] N. Bemrah, M. Sanaa, M. H. Cassin, M. W. Griffiths and O. Cerf, "Quantitative Risk Assessment of Human Listeriosis from Consumption of Soft Cheese Made from Raw Milk," Preventive Veterinary Medicine, Vol. 37, No. 1-4, 1998, pp. 129-145. doi:10.1016/S0167-5877(98)00112-3

[43] V. Babak, J. Schlegelova and H. Vlkova, "Interpretation of the Results of Antimicrobial Susceptibility Analysis of Escherichia coli Isolates from Bovine Milk, Meat and Associated Foodstuffs," Food Microbiology, Vol. 22, No. 4, 2004, pp. 353-358. doi:10.1016/j.fm.2004.08.010

[44] H. Sorum and M. Sunde, "Resistance to Antibiotics in the Normal Flora of Animals," Veterinary Research, Vol. 32, No. 3-4, 2001, pp. 227-241. doi:10.1051/vetres:2001121

[45] B. Catry, H. Laevens, L. A. Devriese, G. Opsomer and A. de Kruif, "Antimicrobial Resistance in Livestock," Journal of Veterinary Pharmacology and Therapeutics, Vol. 26, No. 2, 2003, pp. 81-93. doi:10.1046/j.1365-2885.2003.00463.x

[46] H. Oppegaard, T. M. Steinum and Y. Wasteson, "Horizontal Transfer of a Multi-Drug Resistance Plasmid be- tween Coliform Bacteria of Human and Bovine Origin in a Farm Environment," Applied and Environmental Microbiology, Vol. 67, No. 8, 2001, pp. 3732-3734. doi:10.1128/AEM.67.8.3732-3734.2001

[47] B. R. Berends, A. E. Van den Bogaard, F. Van Knapen and J. M. Snijders, "Human Health Hazards Associated with the Administration of Antimicrobials to Slaughter Animals. Part II. An Assessment of the Risks of Resistant Bacteria in Pigs and Pork," Veterinary Quarterly, Vol. 23, No. 1, 2001, pp. 10-21. doi:10.1080/01652176.2001.9695069

[48] J. W. Chow, V. Kak, I. You, S. J. Kao, J. Petrin, D. B. Clewell, S. A. Lerner, G. H. Miller and K. J. Shaw, "Aminoglycoside Resistance Genes aph(200)-Ib and aac(60)Im Detected Together in Strains of Both Escherichia coli and Enterococcus faecium," Antimicrobial Agents and Chemotherapy, Vol. 45, No. 10, 2001, pp. 2691-2694. doi:10.1128/AAC.45.10.2691-2694.2001

[49] S. Magnet and J. S. Blanchard, "Molecular Insights into Aminoglycoside Action and Resistance," Chemical Reviews, Vol. 105, No. 2, 2005, pp. 477-498. doi:10.1021/cr0301088 